\title{
A comparative study of pre and post vaccinated sera samples of bovine using FTIR spectral analysis
}

\author{
A. Rajalakshmi, S.Gunasekaran ${ }^{1}$ and T.S. Renuga Devi ${ }^{2}$ \\ Sri Chandrasekharendra Saraswathi Viswa MahaVidyalaya, Enathur, Kanchipuram-631 561, Tamilnadu, India \\ ${ }^{1}$ Registrar, Periyar University, Salem-636 011, Tamilnadu, India \\ ${ }^{2}$ P. G. Department of Physics, Women's Christian College, Chennai-600 005, Tamilnadu, India.
}

rajspectrum@gmail.com

\begin{abstract}
This study provides scope for spectroscopic method that can be used as in-vitro test to assess the potent of vaccination instead of conventional in-vivo test. India tops in cattle wealth as well as in milk production in the world. Livestock are to be regularly vaccinated to protect them from many infectious and contagious diseases. We investigated the changes in protein and lipids levels in the pre and post vaccinated sera samples of bovine using FTIR spectral analysis. Two groups of seven animals were vaccinated with Haemorrhagic Septicaemia Vaccine (HSV) and Black Quarter Vaccine (BQV). Pre and post vaccinated sera samples of cattle were collected and tested using Fourier Transform Infra Red (FTIR) spectrometer. Spectroscopic method of blood analysis is an alternate technique to the clinical method since they require fewer samples and provide more information. The variation observed in peaks indicating the change in protein and lipids levels in the animals was due to introduce of antigens. Compared to ELISA, spectral analysis is cost effective test besides it requires small amount of sample for analysis and conforms to bioethics. In vivo challenge test can be replaced once this procedure is standardized which can satisfy the CPCSEA"Committee for the Purpose of Control and Supervision on Experiments on Animal"- which imposes stringent regulations to use animal for experiments.
\end{abstract}

Keywords: Cattle, Livestock, Vaccination, spectroscopy, FTIR spectrometer.

\section{Introduction}

India tops in the world in milk production. In 2003-04 India produced 850 million tons of milk. $15 \%$ of the world's cattle and $57 \%$ of buffaloes are in India. The total number of the cattle in India as per the census of 2003 is 185 million and 98 million buffaloes. Cattle are raised as dairy animals for milk and other dairy products, as livestock for meat (beef) and as draft animals (pulling carts, plough). Other products include leather and useful for natural manure or fuel. In India, cattle are sacred. Livestock are to be regularly vaccinated to protect them from many infectious and contagious diseases. In Tamil Nadu alone as per the 126th livestock and poultry census 2000 , the total cattle population is 93.63 lakhs, which accounts for $35.8 \%$ of the total livestock population in the country (Lingathurai et al., 2009).

Animal diseases can cause enormous economic loss through morbidity and mortality. Vaccination is one of the routine procedures adopted to control specific diseases. It is considered to be the most effective and cost-effective method of preventing infectious disease. The material administrated can either be live, but attenuated forms of pathogens such as bacteria or virus, killed or inactivated forms of these pathogens, or purified material such as proteins. A vaccine administration may be oral, by injection (intramuscular, intradermal, subcutaneous), by puncture, transdermal or intranasal. The immune system recognizes vaccine agents as foreign, destroys them, and 'remembers' them. When the virulent version of an agent enters a body, the immune system recognizes the protein coat on the infective agent, and thus is prepared to respond, by (i) neutralizing the target agent before it can enter cells and (ii) by recognizing and destroying infected cells before that agent can proliferate.

Haemorrhagic septicaemia (HS) is a major disease of cattle and buffaloes occurring in many Asian and African countries, resulting in high mortality and morbidity. In many Asian countries disease outbreaks mostly occur during the change in climatic conditions typical of monsoon (high humidity and high temperature). The disease is caused by Pasteurella multocida, a gramnegative cocco bacillus and aerobbic residing mostly in the upper respiratory tract of animals. Effective vaccines against haemorrhagic septicaemia are formalin-killed bacteria, or dense bacteria with adjuvant. Christopher Hodgson et al. (2004) studied the efficacy of vaccination of calves against Hemorrhagic Septicemia with a Live aroA derivative of P.multocida B:2 by two different routes of administration.

Among the various bacterial diseases affect the animal, Blackleg is one of the fatal disease of young cattle and sheep and occasionally in other animal species. The Black Quarter Vaccine is an Alum precipitated vaccine given to the animals to protect them from the black quarter or black leg disease. The vaccine is prepared from a highly antigenic strain of Clostridium Chauvoeigrown in anaerobic fluid medium, inactivated by formalin and precipitated by adding potassium aluminium
Research article

CIndian Society for Education and Environment (iSee)
"In vitro assessment of vaccination" http://www.indjst.org
Rajalakshmi et al. Indian J.Sci.Technol. 
sulphate. It often occurs at the change from summer to the rainy season.

Srinivasan et al. (2001) assessed the serological response of bovines to combined vaccine containing foot and mouth disease virus, rabies virus, $P$. multocida and C. chauvoei antigens and individual component vaccines also. Serological response of the calves was assayed on days 21 and 90 post vaccination. There was no significant variation in the serological response elicited by individual component vaccines and combined vaccine containing all four antigens.

In serological study, the sample used is very less and hence it is a best method. The fluid portion plasma contains a large number of organic and inorganic substances such as proteins, vitamins, minerals, lipids, etc. Although the main function of blood is to transport various minerals to all cells of the body, blood also provides the temperature regulating a defense mechanism. In this work normal healthy pre vaccinated blood samples (zero day) and post vaccinated $\left(7^{\text {th }}, 14^{\text {th }}\right.$, $21^{\text {st }}$ day after vaccination) blood samples were analyzed by employing FTIR spectroscopic techniques.

\section{Materials and methods}

The experiments were carried out in a village Kaveripakkam, Vellore Dt, Tamilnadu. Blood samples were collected from jugular vein of the healthy cattle. In vaccine production centers or institutes, safety and potency test are conducted regularly to test the quality of the vaccine. The animals are procured from approved contractors with unknown history. The cattle were housed in a clean shed with good ventilation. No antibiotics were given during the experiment period. Pre-vaccinated blood samples were taken. One group of seven animals was vaccinated with $5 \mathrm{ml}$ of black quarter vaccine and the other group of seven animals was immunized with $5 \mathrm{ml}$ of Haemorrhagic Septicaemia Vaccine. Subsequent blood samples were collected on $7^{\text {th }}, 14^{\text {th }}$ and $21^{\text {st }}$ day from the same vaccinated animal. After collecting the blood, the serum was separated. Using the conventional method, the samples were prepared by spreading a small volume of serum on an Infra Red transparent material, allowing drying and measuring the absorption spectrum of the film. Infrared spectroscopy is a powerful method for the study of various biomedical tissue or biofluid samples (Heise, 2008). Shaw et al. (1998) reported that the IR absorption spectrum of thiocyanate ion (SCN) includes absorption at $2060 \mathrm{~cm}^{-1}$ in a spectral region where sera samples and subsequently normalizing all of the spectra to equal intensities therefore compensated for the imprecision in the film preparation. A volume of $1 \mathrm{ml}$ of serum was diluted with an equal volume of $4 \mathrm{mg} / \mathrm{l}$ aqueous potassium thiocyanate (KSCN) solution $20 \mu$ l of each diluted sample was spread evenly over the surface of a circular potassium bromide $(\mathrm{KBr})$ window $(9 \mathrm{~mm}$ diameter and 2 $\mathrm{mm}$ thickness). Infrared spectra in the region 4000-500 $\mathrm{cm}^{-1}$ were recorded on an ABB BOMEM MB SERIES
FTIR spectrometer equipped with an air-cooled DTGS (Deuterated triglycine sulphate) detector. The strong absorption band of water in the mid IR region is hindered and to eliminate in the same, the serum samples were air dried to form a thin uniform film on the $\mathrm{KBr}$ pellet. Infra red transparent $\mathrm{KBr}$ material without the samples was scanned as back-ground for each spectrum and 23 scans were co added at a spectra resolution of $4 \mathrm{~cm}^{-1}$. The collected signal was transferred to the PC. The data were processed by windows based data program-spectrum software. The spectra were base line corrected and they were normalized to acquire identical area under the curves and the maximum absorbance values of the corresponding characteristics bands were noted.

\section{Results and discussion}

Fig. 1 to 4 and 5 to 8 represents the FTIR spectral overlaid curves of cattle vaccinated with $\mathrm{BQV}$ and HSV for the four weeks respectively. The spectra of pre and post-vaccinated sera samples were all distinct from one another, but are dominated mainly by the absorption of the protein constituent which provides the selectivity in infrared based serum analysis. The infrared spectrum provides various useful information of a biomolecule like structure, functional groups, types of bonds and its interactions. Hence, the FTIR spectra of all the sera samples (both pre and post vaccinated) show the corresponding absorption bands in their specific regions qualitatively. But quantitatively there is a considerable spectral difference between the pre and post-vaccinated sera. The absorbance is directly proportional to the concentration. Hence the different sera samples are analyzed quantitatively by calculating the intensity ratio among the absorption peaks (Gunasekaran \& Sankari, 2004). In order to quantify the spectral difference, three intensity ratio parameters have been introduced (Gunasekaran \& Renuga Devi, 2008). The ratios are $\mathrm{R}_{1}=\mathrm{I}_{3296} / \mathrm{I}_{2960}$ due to the $\mathrm{N}-\mathrm{H}$ stretching of secondary amides of proteins and the lipids, $R_{2}=I_{1660} / l_{2874}$ which is due the ratio of intensities of amide-I and amide-II and $R_{3}$ $=I_{1398} / I_{1457}$ due to the ratio of the intensities of $\mathrm{COO}^{-}$ stretching of amino acids $\mathrm{CH}_{3}$ asymmetric deformation. Table 1 and 2 summarizes the internal standard calculations of the pre and post-vaccinated samples of cattle vaccinated with Haemorrhagic Septicaemia Vaccine (HSV) and Black Quarter Vaccine (BQV). In both the tables, the values of $R_{1}, R_{2}$ and $R_{3}$ were found for the pre-vaccinated state. The values were changed in the post vaccinated sera samples due to vaccination. On $21^{\text {st }}$ day of vaccination the values increased compared to the pre vaccinated state for almost all the cattle according to the pre immune status of the animals. These changes were expected due to the increased level of proteins and lipids. Vaccines given to the animals increased the level proteins, lipids, amides and amino acids level in the animal body. It can be compared with other immunity tests in future. The immunity following vaccination is
Research article

CIndian Society for Education and Environment (iSee)
"In vitro assessment of vaccination" http://www.indjst.org
Rajalakshmi et al. Indian J.Sci.Technol. 


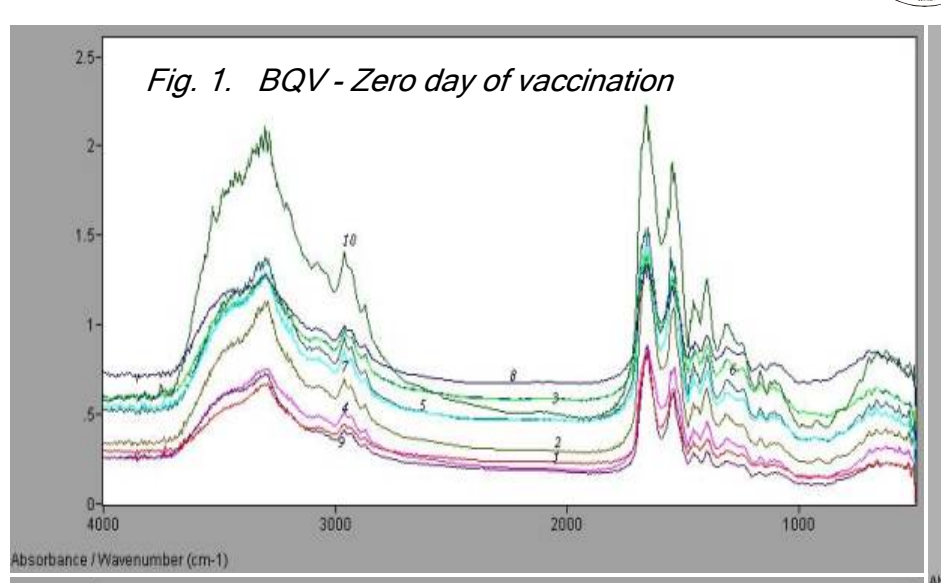

Vol. 3 No. 4 (Apr. 2010)

ISSN: 0974- 6846

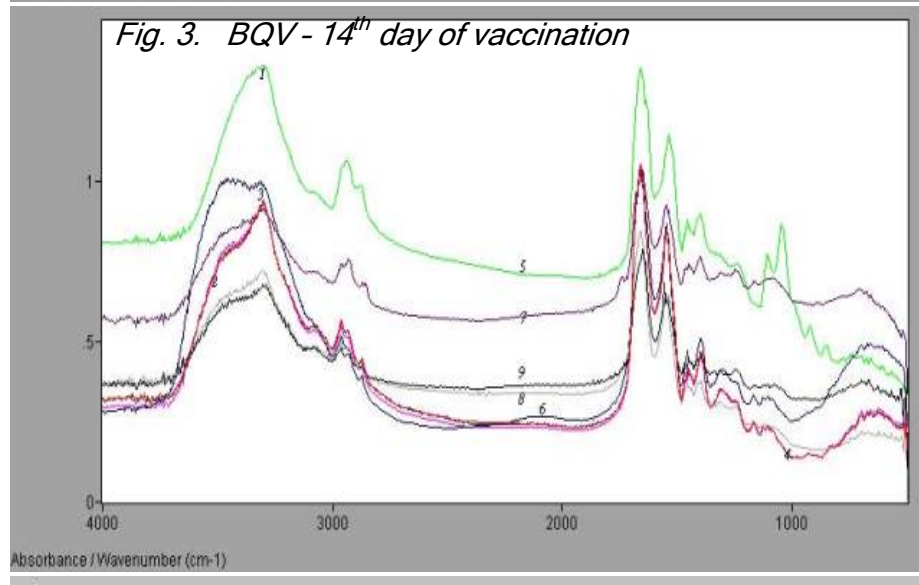

Absorbance I Wavenumber (cm-1)

Fig. 5. HSV-Zero day of vaccination

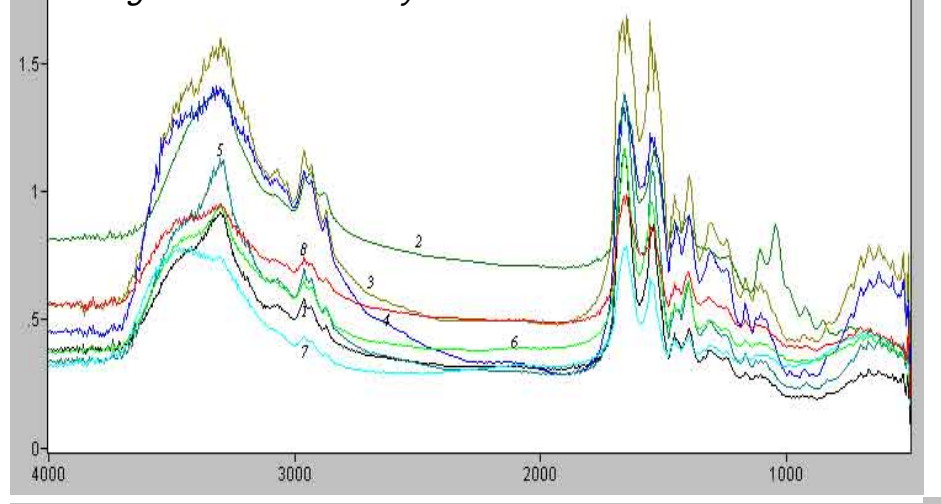

Absorbance / Wavenumber (cm-1)

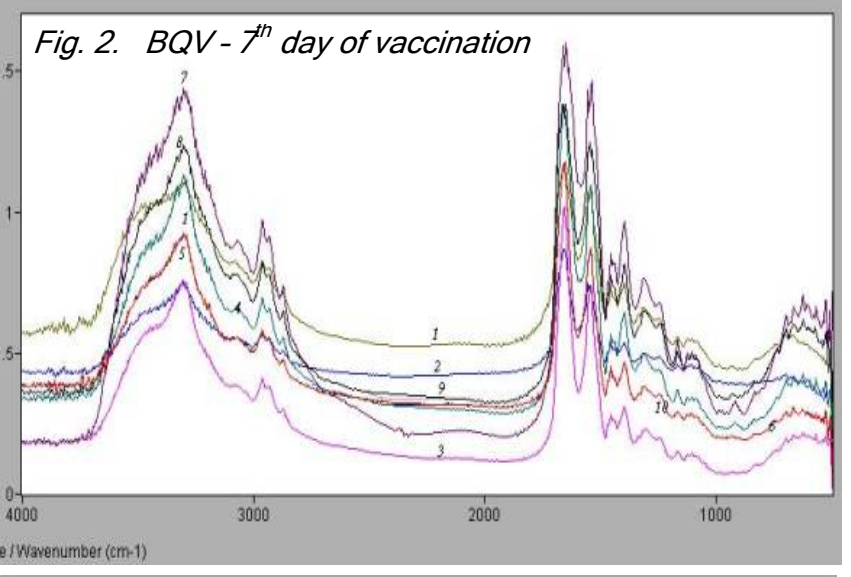

Fig. 4. $B Q V-21^{\text {st }}$ day of vaccination

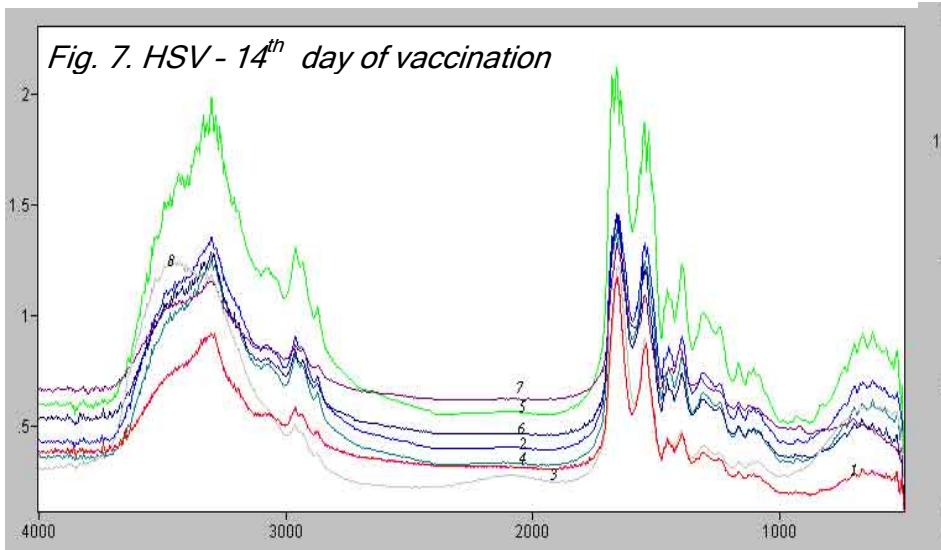

Research article

(C) Indian Society for Education and Environment (iSee)
"In vitro assessment of vaccination" http://www.indjst.org

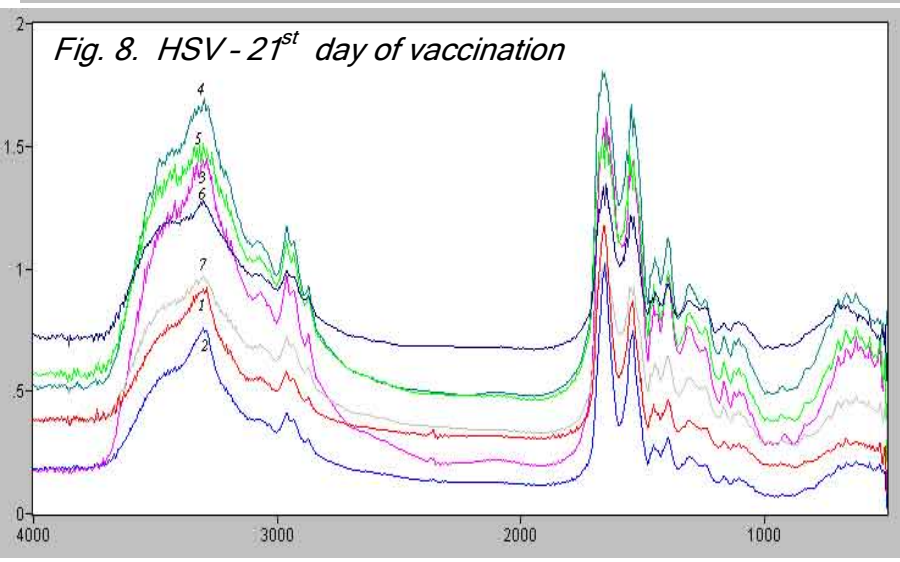

Fig. 6. HSV $-7^{\text {th }}$ day of vaccination

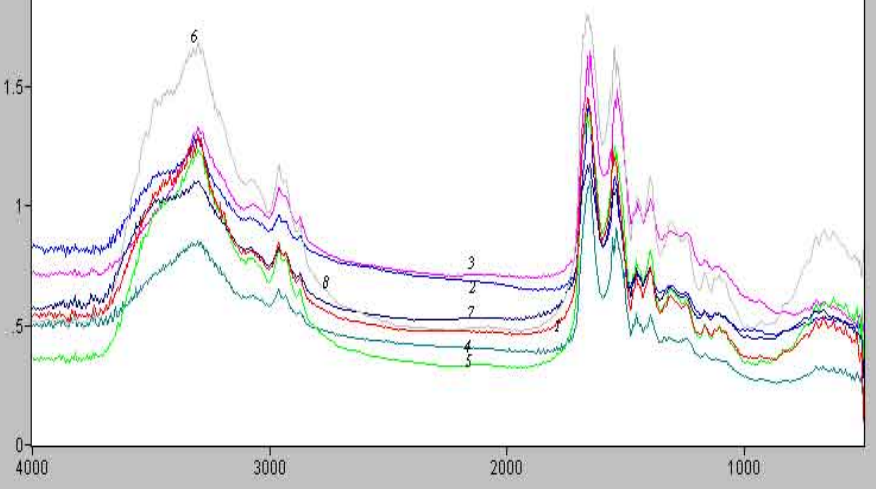

Fig. 8. HSV $-21^{\text {st }}$ day of vaccination

Rajalakshmi et al. Indian J.Sci.Technol. 
Table 1. The internal standard calculations of the pre and post-vaccinated samples of cattle vaccinated with HSV

\begin{tabular}{|c|c|c|c|c|}
\hline Category & Day & $R_{1}=I_{3296} / I_{2960}$ & $R_{2}=I_{1660} / I_{2874}$ & $R_{3}=I_{1398} / I_{1457}$ \\
\hline \multirow[t]{4}{*}{ HSV 1} & pre & 1.576 & 1.041 & 2.454 \\
\hline & post 1 & 1.519 & 1.038 & 2.074 \\
\hline & post 2 & 1.576 & 1.041 & 2.447 \\
\hline & post 3 & 1.586 & 1.038 & 2.472 \\
\hline \multirow[t]{4}{*}{ HSV 2} & pre & 1.324 & 1.011 & 1.371 \\
\hline & post 1 & 1.313 & 1.032 & 1.634 \\
\hline & post 2 & 1.439 & 1.051 & 1.992 \\
\hline & post 3 & 1.791 & 1.092 & 3.454 \\
\hline \multirow[t]{4}{*}{ HSV 3} & pre & 1.367 & 1.077 & 1.804 \\
\hline & post 1 & 1.241 & 1.015 & 1.754 \\
\hline & post 2 & 1.459 & 1.134 & 2.093 \\
\hline & post 3 & 1.255 & 1.038 & 1.464 \\
\hline \multirow[t]{4}{*}{ HSV 4} & pre & 1.311 & 0.982 & 1.986 \\
\hline & post 1 & 1.502 & 1.058 & 2.129 \\
\hline & post 2 & 1.436 & 1.076 & 1.935 \\
\hline & post 3 & 1.597 & 1.141 & 2.404 \\
\hline \multirow[t]{4}{*}{ HSV 5} & pre & 1.474 & 1.053 & 2.012 \\
\hline & post 1 & 1.448 & 1.102 & 2.013 \\
\hline & post 2 & 1.335 & 1.086 & 1.718 \\
\hline & post 3 & 1.425 & 1.176 & 2.187 \\
\hline \multirow[t]{4}{*}{ HSV 6} & pre & 1.436 & 1.076 & 1.94 \\
\hline & post 1 & 1.558 & 1.042 & 1.971 \\
\hline & post 2 & 1.278 & 1.032 & 1.436 \\
\hline & post 3 & * & * & * \\
\hline \multirow[t]{4}{*}{ HSV 7} & pre & 1.748 & 1.005 & 2.155 \\
\hline & post 1 & 1.328 & 1.012 & 1.64 \\
\hline & post 2 & 1.335 & 1.127 & 1.677 \\
\hline & post 3 & 1.328 & 1.046 & 1.651 \\
\hline
\end{tabular}

established in about 10 days and is expected to confer protection against natural infection for a period of six to nine months. Vaccine is advised every year. Vaccination has to be done only under the direct supervision of a veterinarian.

At present experimental animal (maximum of 5) are vaccinated and control animal (2 No's) which are not vaccinated are taken for test. After 21 days, both experimental and control animals are injected with the virulent bacteria or virus. The entire vaccinated animal (experimental animal) will be alive after this test, but the control animals die. This type of vaccine potency test is costly. In future spectroscopic method can be standardized further and can be used as in-vitro test instead of this present in-vivo test. Compared to ELISA, spectral analysis is cost effective test besides it requires small amount of sample for analysis. One instrument can analyze infinite number of samples, since it is window based data program-spectrum software. The spectra were baseline corrected and they were normalized to acquire identical area under the curves and the maximum absorbance value of the corresponding characteristics bands was noted. The internal standards among the absorption peaks can be calculated. By studying this, the potency of the vaccine can be assessed. Spectroscopy has been employed as a diagnostic tool in the study of blood (Renuga Devi et al., 2009).

\section{Conclusion}

This method can be used as a screening test on animals to be vaccinated as well as to assess the potency of vaccine in vaccine production laboratories. This spectral analysis can be effectively used as an in vitro test to screen the animal and also assessing potency of vaccine. In vivo challenge test can be replaced once this procedure is standardized which can satisfy the CPCSEA-"Committee for the Purpose of Control and Supervision on Experiments on Animal"which imposes stringent regulations to use animal for experiments.

\section{Acknowledgement}

AR thanks Dr. A. Singaravelan, Veterinary Assistant Surgeon, Kaverippakam and Dr. M. Ganesamoorthy, Senior Research Officer (Retd) for their guidance.
Research article

CIndian Society for Education and Environment (iSee)
"In vitro assessment of vaccination" http://www.indjst.org
Rajalakshmi et al. Indian J.Sci.Technol. 
Table 2 - The internal standard calculations of the pre and post-vaccinated samples of cattle vaccinated with BQV

\begin{tabular}{|c|c|c|c|c|}
\hline Category & Days & $\mathrm{R}_{1}=\mathrm{I}_{3296} / \mathrm{I}_{2960}$ & $\mathrm{R}_{2}=\mathrm{I}_{1660} / \mathrm{I}_{2874}$ & $R_{3}=I_{1398} / l_{1457}$ \\
\hline \multirow[t]{4}{*}{ BQV 1} & Pre & 1.493 & 2.224 & 1.026 \\
\hline & Post 1 & 1.328 & 1.638 & 1.012 \\
\hline & Post 2 & 1.297 & 1.368 & 1.018 \\
\hline & Post 3 & 1.657 & 2.392 & 1.137 \\
\hline \multirow[t]{4}{*}{ BQV 2} & Pre & 1.603 & 2.375 & 1.136 \\
\hline & Post 1 & 1.325 & 1.712 & 1.006 \\
\hline & Post 2 & 1.604 & 2.274 & 1.121 \\
\hline & Post 3 & 1.611 & 2.473 & 1.136 \\
\hline \multirow{4}{*}{ BQV 3} & Pre & 1.32 & 1.677 & 1.038 \\
\hline & Post 1 & 1.847 & 3.36 & 1.096 \\
\hline & Post 2 & 1.646 & 2.447 & 1.138 \\
\hline & Post 3 & 1.823 & 3.344 & 1.087 \\
\hline \multirow[t]{4}{*}{ BQV 4} & Pre & 1.453 & 2.08 & 1.078 \\
\hline & Post 1 & 1.578 & 2.36 & 1.136 \\
\hline & Post 2 & 1.661 & 2.292 & 1.13 \\
\hline & Post 3 & 1.442 & 2.179 & 1.179 \\
\hline \multirow[t]{4}{*}{ BQV 5} & Pre & 1.475 & 2.048 & 1.062 \\
\hline & Post 1 & 1.576 & 2.524 & 1.04 \\
\hline & Post 2 & 1.274 & 1.268 & 1.018 \\
\hline & Post 3 & 1.32 & 1.677 & 1.038 \\
\hline \multirow[t]{4}{*}{ BQV 6} & Pre & 1.322 & 1.582 & 1.039 \\
\hline & Post 1 & 1.577 & 2.451 & 1.042 \\
\hline & Post 2 & 1.921 & 2.661 & 1.143 \\
\hline & Post 3 & 1.466 & 2.023 & 1.256 \\
\hline \multirow[t]{4}{*}{ BQV 7} & Pre & 1.471 & 2.058 & 1.039 \\
\hline & Post 1 & 1.442 & 2.063 & 1.035 \\
\hline & Post 2 & 1.223 & 1.476 & 1.028 \\
\hline & Post 3 & 1.502 & 2.282 & 1.028 \\
\hline
\end{tabular}

\section{References}

1.Christopher Hodgson J, Anna Finucane, Mark P. Dagleish, Saeed Ataei, Roger Parton and John G. Coote (2004) Efficacy of Vaccination of Calves against Hemorrhagic Septicemia with a Live aroA Derivative of Pasteurella multocida B:2 by two different routes of administration. Infection \& Immunity. 73 (3), 1475-1481.

2.Gunasekaran .S and T.S.Renuga Devi (2008) Analysis of Hyperlipidemic Patients Blood Samples - Spectral and Statistical Implications. Asian J. Clinical Cardiology, 10 (10),14-19.

3. Gunasekaran S and Sankari G (2004) FTIR and UVVisible spectral study on normal and diseased blood samples. Asian J. Chem. 16, 1779-1786.

4. Heise HM (2008) Biomedical vibrational spectroscopyTechnical advances. In: Biomedical Vibrational Spectroscopy. Lasch P \& Kneipp J (Eds.), Wiley. pp: 937.
5.Lingathurai $S$, Vellathurai $P$, Ezil Vendan $S$ and Alwin Prem Anand A (2009) A comparative study on the microbiological and chemical composition of cow milk from different locations in Madurai, Tamil Nadu. Indian J.Sci.Technol. 2 (2), 51-54. Domain site: http://www.indjst.org.

6. Renuga Devi TS, Gunasekaran S, Wesley Hudson J and Sarone Angelah Joybell I (2009) Analysis on renal failure patients blood samples: characterization and efficacy study. Indian J.Sci.Technol. 2 (2), 46-50. Domain site: http://www.indjst.org.

7. Shaw RA, Kotowich $S$, Leroux $M$ and Mantsch $\mathrm{HH}$ (1998) Multianalyte serum analysis using mid-infrared spectroscopy. Ann. Clin. Biochem. 35, 624-632.

8. Srinivasan VA, Reddy GS, Rao KA and Ueli Kihm (2001) Serological response of bovines to combined vaccine containing foot and mouth disease virus, rabies virus, Pasteurella multocida and Clostridium chauvoeiantigens. Veterinarski Arhiv. 71 (1), 37-45.
"In vitro assessment of vaccination" http://www.indjst.org
Rajalakshmi et al. Indian J.Sci.Technol. 